\title{
AIKUISKASVATUSPOLITIIKKA JA VAPAAN SIVISTYSTYÖN JÄRJESTÖT NORJASSA
}

\author{
Artikkeli käsittelee Norjan aikuiskasvatuspolitiikan ja sitä \\ sivuavien rahoituksellisten kannustinjärjestelmien merkitystä \\ vapaan sivistystyön järjestöjen toiminnan sisältöön ja \\ kohdentumiseen. Vaikka tarkastelu rajoittuukin Norjaan, se \\ lienee sovellettavissa muihinkin maihin, joissa käytetään \\ julkisia, vapaaseen sivistystyöhön kohdistuvia \\ kannustinjärjestelmiä.
}

Lähtökohtana on se, että Norjassa vapaan sivistystyön järjestöjen perusta on ollut poliittinen, humanitäärinen tai ideologinen. Alusta lähtien niiden tarkoituksena on ollut heijastaa jonkinasteista sosiaalista sitoutumista. Samalla on todettava, että sosiaalinen sitoutuminen muodostaa sosiaalisen, alueellisen, ikäluokkien ja sukupuolten tasa-arvoistamisen kautta julkisen aikuiskasvatuspolitiikan perustan. Vaikka valtio ja alueelliset viranomaiset rahoittavatkin suuren osan tästä toiminnasta, valtaosa jää järjestöjen kannettavaksi. Lukuvuonna 1987-88 niiden osuus oli yli 85 prosenttia kursseista ja 80 prosenttia kirjoilla olevista osanottajista.

Kaksi suurinta järjestöä, Folkuniversitet ja Työväen sivistysliitto (tästä eteenpäin artikkelissa käytetään pelkästään käsitettä järjestöt, myös tarkoitettaessa näitä kahta vapaan sivistystyön organisaatiota yhdessä), vastasivat yli puolesta aikuiskasvatuksen piiriin kuuluvasta toiminnasta. Vertailun vuoksi voi sanoa, että koulun ja muiden julkisten organisaatioiden opiskelijamäärät muodostivat alle kolme pro. senttia opiskelijamäärästä (Norjan valtion tilastokeskus, 1989).

Toiminta on jakautunut melko tasaisesti eri alueille viimeiset kymmenen vuotta. Kaikkiaan lähes 750000 henkilöä osallistui 73500 julkisin varoin tuetulle aikuiskasvatuskursseille lukuvuonna 1987-88. Tämä vastaa 23 prosenttia yli 16-vuotiaista norjalaisista.
Järjestöjen toimintaperiaatteilla on siis ratkaiseva vaikutus tarjottujen kurssien muotoon ja sisältöön. Asiaan sisältyy olennainen paradoksi. Vaikka aikuiskasvatuslain ensisijaiset tavoitteet koskevat yksilöä, rahalliset resurssit jaetaan järjestöille. Koska järjestöt saavat itse päättää verrattain vapaasti saamansa tuen jaosta, järjestelmä mahdollistaa melko pitkälle lain tavoitteiden vääristymisen. Tämä pätee myös sosiaalisen sitoutumisen sisältämiin tavoitteisiin, joista yhdenvertaisuuden lisääminen on tärkein.

Järjestöjen huomattavien eroavaisuuksien vuoksi aihetta käsitellään ensisijaisesti kahden suurimman vapaan sivistystyön järjestön kannalta, joskin tehdyt havainnot voivat koskea myös useita pienempiäkin järjestöjä ja organisaatioita. Näillä kahdella on muihin verrattuna huomattavan suuri vaikutusvalta poliittisiin päättäjiin. Vaikka aiheen käsittely ei kata kaikkea alalla vallitsevaa monimuotoisuutta, tarkoituksena on silti tuoda esiin vapaan sivistys. työn ja julkisen politiikan suhteeseen liittyvät pääkehityssuunnat ja perusparadoksit.

Aluksi selvitämme sosiaalisen sitoutumisen käsitehistorian ja järjestötaustan. Seuraavaksi tarkastelemme empirisen tutkimuksen perustalla, miten aikuiskasvatuspolitiikan päätavoitteet vastaavat käytännön realiteetteja. Lopussa pohditaan aikuiskasvatuspolitiikan sisäisiä paradokseja sen pyrkiessä säätelemään sivistysjärjestöjen toimintaa sosiaalisen sitoutumi- 
sen periaattein. Tämä vie meidät keskusteluun julkiseen politiikkaan luonnostaan kuuluvista paradokseista ottaen huomioon ko. politiikan kunnianhimon säädellä järjestöjä sosiaalisen sitoutumisen näkymättä.

\section{Sosiaalinen sitoutuminen}

Sosiaalisella sitoutumisella tarkoitetaan tåssä toimenpiteitä, joilla pyritään vaikuttamaan positiivisesti ihmisten elämäntilanteeseen. Se käsittää toimenpiteet, joilla parannetaan sellaisten yksilöiden, ryhmien ja luokkien asemaa, joiden voidaan katsoa olevan sorrettuja, vähäosaisia tai muuten huonommassa asemassa. Näistä mainittakoon työttömät, köyhät, hoitoa vailla olevat fyysisesti tai henkisesti vammaiset sekä työväen luokan osattomat ryhmät (lisää aiheesta julkaisussa Nordhaug 1986).

\section{Lyhyt historiallinen tausta}

Ensi kertaa valtion tukea järjestöjen järjestä. mälle aikuiskasvatukselle jaettiin vuonna 1935. Tuolloin Norjan aikuiskasvatuksessa oli omaksuttu malli, joka pätee vielä nytkin: toiminta perustuu pääosin valtion tukemiin opin= tokerhoihin. (Norjalainen opintokerho vastaa pääpiirteittäin vastaavaa suomalaista.) Rahava. rojen siirtoa lukuunottamatta julkisen vallan rooli oli paljolti passiivinen.

Toisen maailmansodan jälkeen valtio omaksui aktiivisemman roolin useimmilla yhteiskunnan aloilla. Myös aikuiskasvatus joutui valtion lisääntyneen väliintulon kohteeksi. Samalla aikuiskasvatuksen luonne muuttui voimakkaasti. Aikaisemmin sitä oli johdettu paljolti poliittisia, jopa vallankumouksellisia päämääriä kohti (Nordhaug, 1986). Sodanjälkeisinä vuosina, painopiste siirtyi vähitellen yksilön tarpeisiin. Vapaa-aikaan ja harrastuksiin liittyvien kurssien määrä kasvoi nopeasti ja pian niistä tulikin aikuiskasvatuksen hallitseva alue. Valtaosa kursseista oli tarkoitettu edistä. mään kurssilaisten itsensätoteuttamisen tarvetta yksilösuoritusten kautta. Tähän vaikutti paljolti se, että järjestöt suuntautuivat enenevissä määrin aikuiskasvatusmarkkinoiden luomiseen. Suuntausta tuki mitä todennäköisemmin sodan myötä maan vallannut konsensus ja maan joutuminen saksalaisten miehittä. mäksi. Ilmapiiri ei suosinut avointa luokka- tai ryhmäetutaistelua. Maan jälleenrakentaminen oli kaiken kattava yhteinen tavoite, ja luokka. rajat ylittävä yhteistyö oli keino sen saavutta. miseksi (Bergh, 1977; Grnlie, 1977). Tämän seurauksena poliittisen ja ideologisen koulutuksen merkitys väheni työväenliikkeen sisällä aiempaan verrattuna (Lundestad, 1977; Stenersen, 1977).

Filantropiset liikkeet kokivat samankaltaisen muutoksen. Kun pahin köyhyys oli voitettu ja työväenliike oli saavuttanut valtaa sekä eduskunnassa että hallituksessa, ja kun lukutaidottomuustilanteeseen oli saatu kohennus: ta, filantropisesti suuntautuneet järjestöt muuttivat toimintaperiaatteitaan ja ryhtyivät pääasiassa huolehtimaan markkinoiden tarpeista. Ne käynnistivät laajan kurssivalikoiman markkinoinnin ja myynnin sen sijaan, että aikaisemmin niiden tarjoama aikuiskasva. tus oli ollut maksutonta, koska oli ollut opiske. lijoita, jotka olivat opettaneet vähäosaisia tovereitaan palkkiotta idealistisista syistä (vrt. Sollid, 1982).

Sodan ja aikuiskasvatuslain voimaantulon välinen aika oli vähenevän sosiaalisen sitoutu. misen aikaa. Tämä oli seurausta sekä järjestő. jen kasvavasta markkinahenkisyydestä ja julkisenhallinnon mukaan tulosta aikuiskasvatussektorille.

Aikuiskasvatuslain voimaantulo vuonna 1977 muodostui käännekohdaksi Norjan aikuiskasvatuksen historiassa. Se merkitsi aikuiskasvatuksen täydellistä sisällyttämistä hyvinvointivaltion käsitteeseen: lain myötä valtio otti julkisen vastuun aikuiskasvatuksesta. Lisäksi viranomaisille siirtyi pääosa siitä vastuusta, joka oli aikaisemmin ollut järjestöillä.

\section{Järjestökehitys}

Seuraavassa käsitellään järjestöjen kehitystrendejä sekä niiden osuutta sosiaalisessa muutoksessa ja sosiaalisen sitoutumisen va. kiinnuttamisessa.

\section{Muodonmuutos}

Järjestöt ovat muuttuneet johtuen osittain julkisen vallan voimakkaasta mukaantulosta aikuiskasvatukseen ja toisaalta organisaatiodynamiikasta. Jäsenistön idealismiin perustuneet järjestöt byrokratisoituivat ja tavoittelivat tehokkuutta ja kasvua. Samalla nykyiset jär. jestöt näyttävät kiinnostuvan vähemmän yhteiskunnallisesta muutoksesta kuin palvelujensa markkinoimisesta ja myymisestä mahdollisemman monelle niitä tarvitsevalle (Knudsen $\mathcal{E}$ Ulset, 1980; vrt. myös Brostrm E Ekeroth, 1977). Monet merkit viittaavat siihen, että idealismi on muuttunut kaupallisuudeksi.

Aikaisemmin järjestöjen toiminta erottui helposti yleisen koululaitoksen toiminnasta. 
Nykyisin näyttåå kuitenkin siltä, ettå nämä kaksi järjestelmää ovat ajautumassa yhteen. Järjestöjen harjoittama aikuiskasvatus on muodostumassa yhä enemmän perinteistä koulujärjestelmåå täydentäväksi (vrt. Rubenson, 1980:36-39).

Eräs tapa tulkita tätä suuntausta on lähteä siitä olettamuksesta, että järjestöt ovat melko pitkälle integroituneet valtiomekanismiin. Ne täyttävät verrattain joustavasti ja tehokkaasti niitä tehtäviä, jotka usein jäävät tavalliselta koulujärjestelmältä ja yliopistoilta täyttämättä. Kyseiset tehtävät liittyvåt pääasiassa yhteiskunnan kulloisiinkin tarpeisiin järjestää kestoltaan lyhyempiä, erikoistuneempia koulutuspalveluja, kuin mitä koulut tai yliopistot pysty. vät tarjoamaan. Näyttåä myös siltä, että järjestöt pystyvät paremmin sopeutumaan nopean teknisen kehityksen luomiin koulutustarpeisiin. Vapaaehtoisuusluonteensa ja improvisoinnin värittämien perinteidensä vuoksi niitä yleensä pidetäån joustavampina kuin perinteisiä kasvatusinstituutioita.

Järjestöjen ja koulujärjestelmån yhdistyminen vaikuttaa todennäköisesti siihen, missä määrin sosiaalista sitoutumista halutaan ilmaista. Mitä enemmän järjestöt osallistuvat välineelliseen, suorituspisteitå antavaan opetukseen, sitä vähemmän niillä on resursseja sosiaalista sitoutumista ilmentävään toimin. taan. Tästä seuraa, että sitoutumisen julkituonti jää yhä enemmän julkisen hallinnon viranomaisten tehtäväksi.

\section{Yhteiskunnallisen muutoksen eståminen}

Samalla, kun markkinointi ja myyminen ovat nousseet järjestöissä etualalle, taistelu yh. teiskunnallisen muutoksen puolesta on siis haihtunut lähes olemattomiin. Tätä tärkeämpi kysymys on kuitenkin se osallistuvatko järjes. töt mahdollisten muutosten estämiseen.

Yksi tapa lähestyä kysymystå on tutkia valtionapujärjestelmän toimintaa, lähtökohtana valtionapuun oikeutettujen järjestöjen valinta. Nykyåän tällaisia jårjestöjä on noin neljäkym. mentä. (Mäårääå supistamisesta 15:een on annettu huhtikuun lopulla 1991 lainmuutosesitys; toimituksen huomautus, ks. sivu.) Kuten arvata saattaa, viranomaiset ovat haluttomia ottamaan tukijärjestelmäån mukaan uusia jär. jestöjä. He ovat luonnollisesti hyvin tietoisia siitä, että avun kokonaismäärää ei nosteta automaattisesti mikäli avustettavien järjestöjen lukumäärä nousee.
Korporatiivisten sääntöjen tapaan mukana olevilta järjestöiltä tiedustellaan niiden kantaa aina, kun jokin järjestö pyrkii tuen piiriin ja kannanotot tulkitaan voimaperäisiksi poliittisiksi signaaleiksi. Tästä seuraa, että nuoret tai hiljattain perustetut, yhteiskunnallisen muutoksen puolesta toimivat eri alojen järjestöt tuskin pääsevät nauttimaan julkisesta aikuiskasvatustuesta. Näin ollen niiden työskentelyolosuhteet muodostuvat vaikeammiksi, kuin jos niiden sallittaisiin päästä valtionapujärjes. telmån piiriin.

Norjalaiset politiikan tutkijat ovat kiinnittäneet huomiota siihen, että samalla kuin etujärjestöt ja kansanliikkeet ovat entisestään komplisoituneet ja byrokratisoituneet, on tullut esille myös uusia "ruohonjuuritason" vaikutuskanavia. Tärkeimpiä niistä ovat poliittiset ja usein paikalliset yhdenasianliikkeet (Olsen E Saetren, 1980). Mainitut liikkeet eivät kuitenkaan saa julkista tukea millekään mahdollisesti järjeståmålleen kurssille, vaikka niillä usein onkin akuutti tarve sivistää ja kouluttaa jäsenistöään ja kannattajiaan. Samalla suuret vapaan sivistystyön organisaatiot, olivatpa ne etujärjestöjä tai eivät, nähdåän tavallisesti val. litsevan järjestelmän jatkeina, ts. niiden ei katsota uhkaavan sitä. Niiden turvattu asema Norjan korporatiivisen poliittisen rakenteen sisällä merkitsee myös sitä, että ne ovat epäto. dennäköisiä radikaalin muutoksen lähteitä yhteiskunnallisessa rakenteessa. Näin ollen, Norjan tilanteelle on ominaista se, että poten. tiaalinen yhteiskunnallinen muutosta näyttää rajoittavan järjestöjen ja yhteiskuntapolitiikan yhteisvaikutus.

\section{Sitoutumisen vakiinnuttaminen}

Aivan kuten aikuiskasvatus vakiinnutettiin sodan jälkeisinä vuosina, myös sosiaalinen sitoutuminen on pitkälti vakiinnutettu - lähinnå siksi, että aikuiskasvatuksesta on tehty osa hyvinvointivaltiota. Tämä paljastaa erään erittäin merkittävän paradoksin, joka ei rajoitu pelkästään aikuiskasvatukseen. Kun yhteiskunnallisten kysymysten hoito siirretään niin sanotusti julkisen hallinnon tehtäväksi, on niille järjestöille, jotka aikaisemmin osallistuivat noiden kysymysten hoitoon, usein tyypillistä vetåytyminen taka-alalle. Luotetaan siihen, ettå valtio hoitaa asiat kuntoon. Voi olla, että tässä heijastuu osin voimakas usko yhteiskunta. politiikan tehokkuuteen ja johdonmukaisuuteen yleensäkin ja osin se käsitys, että mainittujen asioiden hoito siirtyy valtion erityistehtäväksi, ellei erityistukea myönnetä järjestöille. Seurauksena on se, että järjestöjen sosiaalista 
sitoutumista motivoivat ensisijaisesti rahoitukselliset näkökohdat.

Sitten on vielä niin, että erityisen voimak. kaita aikuiskasvatuksellisia tarpeita omaavat yksilöt ja ryhmät on identifioitava ja todettava kelvollisiksi nauttimaan valtion tukea. Niinpä vaa'an kieleksi muodostuukin viranomaisten yleisnäkemys yhteiskunnan sosiaalisista ja kulttuurisuhteista. Mikäli tukijärjestelmän tarkoituksena on edistää ryhmien välistä tasa-arvoa, viran-omaisten on välttämättä oltava jatkuvasti selvillä väestörakenteesta ja sen "ryhmittymistä". Valtiokoneistoa ei ole kuitenkaan perustettu eikä se ole erityisen hyvin varustautunut tilastoissa näkymättömän "piiloyhteis. kunnan" jäljittämiseen (vrt. Lund \& Nord. haug, 1985:11; Nordhaug, 1991).

Toisaalta vähäosaisten ryhmien valitseminen voitaisiin delegoida järjestöille. Ongelmaksi muodostuu kuitenkin se, että nämä järjestöt eivät todennäköisesti ryhtyisi kartoittamaan yhteiskunnallisia epäkohtia tai poikkeavia alakulttuureja, ellei erityisiä julkisia taloudellisia kannustimia olisi tarjolla. Niin kauan kun tukirahat on kytketty oppikursseihin eikä tutkimukseen, järjestöjen ponnistelut voivat mennä hukkaan, mikäli ne eivät voi muuttaa tutkimustoimintaa kurssitoiminnaksi.

\section{Ihanteet ja tosiasiat}

Aikuiskasvatuksen sosiaalinen sitoutuminen oli alusta saakka sen luonteva toiminnan osa. Tapa, jolla sorretut talonpojat ja työväen. luokka hyödynsivät sitå luokkataisteluissa, oli jo itsessään heijastus sosiaalisesta sitoutumisesta. Myöhemmin sitoutuminen vakiintui; aluksi siten, että kansanliikkeet ja aikuiskasvatusorganisaatiot laitostuivat, jonka jälkeen kehitettiin aikuiskasvatuspolitiikka, jonka tavoitteena oli kompensoida markkinoiden yhteiskunnalliset vinoutumat. Seuraavaksi arvioim. me tämän politiikan vaikutusta vertaamalla sen yhdenvertaistamistavoitteita empiirisen tutkimuksen dokumentoimaan todellisuuteen.

\section{Ihanteet}

Norjan aikuiskasvatuslaki tuli voimaan vuonna 1977. Sen tarkoituksena on säädellä sitä osaa aikuiskasvatuksesta, jota julkiset viranomaiset tukevat. Laki tekee selväksi sen, että julkisen aikuiskasvatuksen päätavoite on tarjota yksilöille tasaveroiset mahdollisuudet. Tasapuolisuus tässä yhteydessä ei kuitenkaan rajoitu muodollisiin oikeuksiin osallistua aikuiskasvatukseen. Tarkoituksena on ollut vähintään varmistaa, että pitkälle koulutetut ja muissakin suhteissa resursseja omaavat henkilöt eivät olisi yliedustettuina valtion tukemilla kursseilla.

Tapana on kuitenkin ollut tulkita näitä tavoitteita, ikään kuin ne kohdistuisivat ensisijaisesti eri yhteiskuntaryhmien väliseen yhden. vertaistamiseen (vrt. Kallerud, 1978). Tähän sisältyy voimakkaampi tasa-arvonormi, jonka loogisena seurauksena voidaan pitää sitä, että pitkälle koulutettujen henkilöiden ryhmä saisi olla aliedustettuna aikuiskasvatuksessa (eri ta. sa-arvotavoitteita käsitellään $\mathrm{mm}$. teoksissa Hernes, 1974; Okun, 1975). Tämän kaltainen normi tuotiin esille eräässä lakia edeltäneessä raportissa. Siinä todettiin, että ellei aikuiskasvatuksesta osalliseksi pääsemiseen liittyvää muodollista tasa-arvoa täydennetä vähäosaisia koskevilla erityistoimenpiteillä, tulevat olemassaolevat koulutukselliset eriarvoisuudet kasvamaan (Ot.prp.nr.7, 1975). Esimerkiksi ikäluokkia koskevissa eriarvoisuuskysymyksissä on pyritty kaventamaan vanhojen ja nuorten välistä koulutuksellista kuilua tarjoamalla vanhemmille ihmisille sitä koulu. tusta josta he ovat jäänet paitsi nuoruudessaan (Ot.prp. nr.7, 1975:24; Kallerud, 1978:40-41; St.meld. nr.72:19).

\section{Sosiaalinen näkökulma}

Tässä yhteydessä sosiaalisella näkökulmalla tarkoitetaan resurssien jakautumista kaikissa sosio-ekonomisissa ryhmissä erotuksena sukupuolen, iän tai maantieteellisen sijainnin määräämistä ryhmistä.

Aikuiskoulutukseen osallistumisessa on tuntuvia koulutuksen tasoon liittyviä eroja. Useat tutkimukset ovat osoittaneet, että ne henkilöt, joilla on ainoastaan pakollinen koulutustausta osallistuvat tuntuvasti harvemmin koulutukseen kuin ne, joilla on enemmän koulutusta (esim. Knudsen E Skaalvik, 1979; Nordhaug, 1983; Setsaas, 1985). Mikäli koulutustasoa käytetään sosio-ekonomisen statuksen indikaattorina, aikuiskasvatuspolitikan ihanteiden ja realiteettien välillä on havaittavis. sa tuntuva kuilu.

On väitetty, että järjestöjen rooli tässä asetelmassa ei olisi tärkeä, koska niiden tarjonnan kulttuurirakenne koskee enemmån hyvin kou. lutettujen ihmisten elämäntilannetta ja mieltymyksiä kuin niiden, joilla on vaatimaton koulutustausta. Kritiikkiä on esitetty myös sen johdosta, ettei viimeksi mainittua ryhmää ole riittävästi lähestytty. Empiiristä tutkimustietoa tämän väittämän tueksi tai sen kumoamiseksi ei kuitenkaan ole. 


\section{Sukupuolinäkökulma}

Yhdenvertaistamistavoitteista huolimatta viranomaiset eivät ole juuri ryhtyneet toimenpiteisiin laajentaakseen sukupuolten tasa-arvoa aikuiskasvatuksessa. Eräs syy passiivisuuteen lienee siinä, että naiset ovat perinteisesti osallistuneet miehiä vilkkaammin (Nordhaug, 1984a; Norjan tilastokeskus, 1989). Osallistumismallien tarkastelu paljastaa kuitenkin melkoisia eroja. Itse asiassa oppiaineiden va. linnassa on yksi selvästi miehinen malli ja toinen selvästi naisellinen malli. Naiset ovat vah. vasti yliedustettuja humanistisissa aineissa, estetiikassa sekä sosiaali- ja terveydenhoidossa. Miehet taas ovat yli-edustettuja hallinto., talous- ja lakiaineissa sekä maa- ja metsätaloudessa. Lisäksi miehillä on taipumusta osallistua pidempiin kursseihin (laskenta perustuu Norjan tilastokeskuksen tietoihin, 1989).

Kaikkiaan näyttääkin selvästi siltä, että ainevalintoihin liittyvä osallistumismalli heijastaa suurelta osin yhteiskunnassa vallitsevaa sukupuolten työnjakoa. Paradoksaalista on, että todellisuudessa aikuiskasvatus näyttää osaltaan vahvistavan em. työnjakoa, vaikka tavoitteena onkin aikaansaada miesten ja naisten välinen tasa-arvo.

Tämän lisäksi havaitut erot korostavat ra. kenteellisten tekijöiden voimaa ja selventävät sitä marginaalista roolia, joka aikuiskasvatuspolitiikalla sittenkin saattaa olla huolimatta sen kunnianhimoisista tavoitteista. Lisäksi ei ole mitään syytä olettaa, että järjestöt olisivat lainkaan kiinnostuneita tämän mallin muuttamisesta - mallin, joka on pohjimmiltaan yksilöiden vapaasti tekemien valintojen summa.

\section{Ikåluokkanäko̊kulma}

Aikuiskasvatuslain eräs voimakkaimmin esitetyistä tavoitteista pelkistyy poliittisessa iskulauseessa "oikeutta vanhemmille sukupolville ennen kuin se on liian myöhäistä". Ennen lain voimaantuloa oli vallalla käsitys, että aikuiskasvatus olisi ikäluokkia yhdistävä koulutussilta. Tämä näkemys oli varsin optimistinen, kun otetaan huomioon tuolloin tarjolla olleen kansainvälisen tutkimusaineiston määrä. Moni poliitikko näyttää kuitenkin hairahtu. neen kannattamaan tuolloin orastunutta elinikäisen oppimisen ihannetta ja sen tarjoamia mahdollisuuksia (vrt. Blaug \& Mace, 1977).

Vapaa-ajan viettoon liittyvien kurssien osalta kurssilaisten määrissä havaittava epäsuhta ikäluokasta toiseen on pysynyt melko muuttu. mattomana norjalaisessa aikuiskasvatuksessa
(Aamodt, 1976; Knudsen E Skaalvik, 1979; Setsaas, 1985). Työhön liittyvillä kursseilla, joista valtaosa jää tukijärjestelmän ja lakisää. döksien ulkopuolelle, on toisaalta voitu kirjata suuntaus tasasuhtaisuuteen (Nordhaug, 1984a:193). On kuitenkin huomattava, että tällä aikuiskasvatuksen sektorilla näitä suuntauksia el voida pitää seurauksina lain voimaantulosta. Ne johtuvat työelämässä tapahtuneista muutoksista. Siksi onkin paradoksaa. lista, että on tapahtunut edistystä ikäluokkien välisen tasa-arvon suuntaan sellaisella aikuiskasvatuksen alueella, johon em. laki ei vaiku. ta. Siellä missä laki vaikuttaa, sitä ei sen sijaan ole tapahtunut.

Eräs syy vanhempien ihmisten vähäiseen osallistumiseen saattaa löytyä itse järjestöistä. Niiden kannalta on rationaalista keskittää resurssit markkinoiden suurimpiin segmentteihin - nuorisoon ja keski-ikäisten ryhmään. Todennäköisenä seurauksena on tuntuvasti kaventunut vanhempiin ikäluokkiin kohdistu. va tarjonta. On myös mahdollista, että useiden tutkimusten osoittama vanhempien ihmisten vähäinen osallistuminen on rajoittanut järjestöjen panostusta tähän ryhmään.

Aikuiskasvatuslaki määrittelee vanhemmat henkilöt yhdeksi ns. prioriteettiryhmäksi. Niinpä heidän tarpeistaan lähtevät kurssit saavatkin suosituimmuustukea, joka on tavallista edullisempaa järjestöille. Näyttää kuitenkin käyneen niin, että aikuiskasvatuslain astuttua voimaan osa tälle ryhmälle tarkoitetuista kurs. seista rahoitettiinkin vähäosaisille ryhmille tarkoitetulla suosituimmuustuella.

Vapaata sivistystyötä harjoittavien järjestöjen aikaisempi käytäntö oli ollut rahoittaa vanhemmille ihmisille tarkoitettu kurssitoiminta tavanomaisesta opintokerhotuesta. Tämä oletettu järjestöllinen toiminta havainnollistaa erästä yleistä valikoivan tuen kohdistukseen liittyvää ongelmaa: heti kun jokin valikoiva järjestely on saatu palvelemaan tiettyä ryhmää, on järkevää, että järjestöt määrittelevät mah. dollisemman suuren osan jo olemassa olevas. ta toiminnastaan suosituimmuustuen piiriin kuuluvaksi saadakseen enemmän tukea myös niihin toimintoihin, joita ne olisivat har. joittaneet joka tapauksessa suosituimmuus. tuesta huolimatta. Siksi onkin mahdollista, että valikoivan järjestelyn tarkoitettu vaikutus itse asiassa jää aiottua vähäisemmäksi ja eräillä aloilla jopa heikkenee.

\section{Paradoksit}

Seuraavassa identifioidaan ja käsitellään kaksi paradoksia, jotka liittyvät yhteiskunnan 
harjoittamaan aikuiskasvatuspolitiikkaan ja järjestöjen käyttäytymiseen sellaisessa tilanteessa, jota leimaa yleinen, yhdenvertaistamiseen tähtäävä politiikka.

\section{Paradoksi 1: Yksilo̊ vastaan yhteiso̊}

Julkisessa aikuiskasvatuspolitiikassa esitetyt tavoitteet ja niiden saavuttamiseksi käytetyt keinot on suunnattu yksilöihin. Päämääränä on ollut luoda suurempaa aikuisten välistä tasa-arvoa ja niinpä kollektiiviyksikkökäsitteitä on käytetty pelkästään tilastollisessa mielessä (esimerkiksi sosiaalinen ryhmä, vanhukset). Painopiste on ollut yksilöiden kyvyssä tulla toimeen eri rooleissa.

Mahdollisuudet saavuttaa yhdenvertaisuus ja sellainen tilanne, jossa syrjintää ei tapahdu, voidaan kuitenkin kyseenalaistaa, kun keskitytään vain yksilöihin suunnattuihin keinoihin. Tämä suuntaus edustaakin jonkin asteista pa. radoksia siksi, että ihmiset elävät ja toimivat kollektiiviryhminä - esimerkiksi perheinä, ryhminä, alakulttuureina ja järjestöinä.

Eräät tutkijat ovat tulkinneet aikuiskasva. tuksen rakenteen olevan heijastus sen käyn. nistäjien ja järjestäjien intresseistä ja kulttuuriarvoista. Vallitsevan käsityksen mukaan järjestöjen työntekijät ovat pääasiassa henkilöitä, joiden aikuiskasvattajan työ on perinteisten keskiluokkaisten arvojen läpäisemä. Tästä seuraa, että myös kurssien sisältö heijastaa keskiluokan arvoja ja harrastuksia (Miller, 1967; Newman, 1979:26). Westwood päätti aikuiskasvatuksen ja kasvatussosiologian välistä suhdetta käsittelevän tarkastelunsa tavalla, joka hyvin havainnollistaa tätä keskiluokka. vinoutumaan kohdistuvaa arvostelua: "... Haluaisin esittää, että aikuiskasvatus kulttuurin alueena määriteltäisiin uudelleen sellaiseksi alueeksi, jossa työväenluokan kulttuurillinen pätevyys on yhdenvertainen keskiluokan kanssa" (Westwood, 1980:44).

Tämä arvostelu vie meidät seuraavaksi kol. lektiiviseen tarkasteluun. Voidaan väittää, että ennen kuin aikuiskasvatuksesta tulee yhdenvertaistava väline, tarvitaan myös keskiluokasta poikkeaviin ryhmiin kohdistuvaa ja niiden taholta tulevaa kollektiivistä panostusta (esim. Lovett, 1982). Tämä edellyttää, että mainitut ryhmät vakiinnuttavat omiin lähtökohtiinsa perustuvan aikuiskasvatusjärjestelmän. Ellei näin tapahdu, jää muille ryhmille suuntautuvan tarjonnan laatiminen keskiluokkaan kuuluvien aikuiskasvattajien tehtäväksi - ja se olisi enemmän hyväntekeväisyyteen vivahtava tapa suhtautua mahdollisiin muutoksiin. Mikä- li kulttuuriltaan "poikkeaville" ryhmille käynnistetään tarjontaa, on tarjonnan tuottaminen vaikeaa, elleivät ryhmien jäsenet itse aktiivisesti osallistu siihen.

Tätä taustaa vasten on kysyttävä, kuinka viranomaiset politiikallaan aikovat tehdä mahdolliseksi eri kulttuureja edustavien ryhmien omiin lähtökohtiinsa perustuvan aikuiskasva. tustoiminnan käynnistymisen. Tuntuu kohtuulliselta olettaa, että Norjan nykyinen valtio. napujärjestelmä ei pysty merkittävåssä määrin aikaansaamaan tämän suuntaista kehitystä. Se perustuu byrokraattisiin lähtökohtiin, jotka hallitsevat julkisyhteisöjen ja vakiintuneiden järjestöjen suhdetta. Siksi ratkaisevaksi seikaksi muodostuukin, pystyvätkö järjestöt havaitsemaan ja ymmärtämään eri yhteiskunta. ryhmien tarpeet. Tämän lisäksi on tärkeää ky syä voivatko ne ja haluavatko ne käynnistää erityistoimintoja yhteistyössä muiden ryhmien edustajien kanssa (vrt. Kallerud, 1978).

Yhteistyön käynnistyminen vaikuttaa epä. todennäköiseltä, elleivät viranomaiset ole jostain syystä luokitelleet kyseistä ryhmää erityisen tärkeäksi. Muussa tapauksessa opinto-or ganisaatiot menettäisivät rahaa toiminnan jär. jestämisessä verrattuna siihen rahalliseen tulokseen, jonka ne saavuttaisivat käyttämällä resurssejaan maksukykyisempiin, panosta. malla vahvempiin ryhmiin. Päädymme seu. raavaan tilanteeseen: järjestöt järjestävät erityistoimintoja keskiluokkaan kuulumattomille ryhmille tavallisesti vain, jos ihmiset järjestäy. tyvät ryhmiksi, jotka kykenevät tuornaan tarpeensa esille tavalla. Heidän on lisäksi tuotava se esille tavalla, joka varmistaa niille rahallisen prioriteettiaseman aikuiskasvatuspolitiikassa. Tämän jälkeen on kohtuullista olettaa, että näiden ryhmien onnistuminen vakiinnuttaa toimintonsa riippuu niiden muodollisesta organisointiasteesta. Koska on tiedossa, että monet alakulttuurit ja ryhmät ovat vailla tämän kaltaista organisointia, tulevaisuuden odotukset eivät näytä kovin lupaavilta. Haaste tilanteen muuttamiseksi on luultavasti kaikista pulmallisin sekä yhteiskunnan että järjestöjen kannalta katsottuna.

Miller (1967:14-15) ja Rubenson (1977) ovat tuoneet esille ajatuksen, jonka mukaan ammattiyhdistykset ja muut vapaaehtoisjär. jestöt, joiden jäsenistö kuuluu pääosin työväenluokkaan, olisivat erityisen tehokkaita värväämään vähän koulutettua väkeä aikuiskasvatuksen piiriin. Opiskelijamäärävinoutumat olisivat varmaankin vieläkin huomattavampia ilman niiden panostusta. Tämä ei kuitenkaan auta ratkaisemaan järjestäytymättömien tai huonosti järjestäytyneiden ihmisten 
ja ryhmien ongelmia (kts. Martinussen, 1977).

\section{Paradoksi 2: Per capita versus valikoiva tuki}

Edellä on todettu, että valtaosa organisoidusta aikuiskasvatuksesta Norjassa (poislukien henkilöstökoulutus) saa valtionapua. Julkisen sektorin rooli on siis ratkaisevan tärkeä. Toisaalta suurin osa tuen piirissä olevasta toiminnasta tapahtuu ei-kaupallisissa järjestöissä (l. "kolmas sektori"). Niitå ovat tutkineet Weisbrod (1988) ja Van Til (1988). Vaikka valtio myöntää tukea pienryhmäopiskeluun, viranomaisten valta järjestöjen tarjoaman opetuksen sisältöön ja kohderyhmävalintoihin on vähäinen. Mutta luultavasti juuri viranomaisten myöntämä tuki pitää kurssimaksut alhaisina ja oletettavasti myös lisåå hakeutumista opiskeluun. Lopputulos on varmaankin sosiaalisesti tasa-arvoisempi kuin julkisen tuen puuttuessa.

Tuen jakotapa on kuitenkin kyseenalainen siksi, että kukin osallistuja hyötyy periaatteessa yhtä paljon valtion tuesta: varakkaat samal. la tavalla kuin vähävaraisetkin. Tåtä voidaan kutsua per capita -periaatteeksi /Hernes, 1978; vrt. myös Wildavsky, 1987). Käsitteenä se tarkoittaa, että julkisten resurssien täy. tyy tavoittaa mahdollisimman monta henkilöä, jolloin lopputuloksena on hyödynsaajien maksimoinnin kautta maksimaalinen hyvinvointi. Yhdenvertaisuuden saavuttaminen edellyttää kuitenkin resurssien valikoivaa jakamista vähävaraisille ryhmille.

Per capita -tavoitteiden ja tasa-arvotavoitteiden välisessä ristiriidassa, johon skandinaavisessa aikuiskasvatuskirjallisuudessa usein viitataan rahanjakopolitiikan ja palvelupolitiikan välisenä ristiriitana, on nähtävissä eräs norjalaisen yhteiskuntapolitiikan pääongelmista tällä sekä muillakin aloilla (Brostrm E Ekeroth, 1977; Kallerud, 1978; Nordhaug, 1982: 2.l.).

Valikoivien tukimuotojen lisääminen suhteellisen vähävaraisten osanottajien mukaansaamiseksi ja heidän tukemisekseen vastaa sitä, että lisättåisiin yleisen (lähinnä opintokerhotyyppisen) aikuiskasvatuksen tarjontaa. Sitä kautta luotaisiin jyrkempiä rajoja julkisen ja yksityisen sektorin (mukaanlukien ei-kaupallinen sektori) välille.

Tasa-arvopolitiikan ja koulutustuen uusjaon edistäminen markkinoiden kautta ei ole kuitenkaan mahdollista. Voi olla, että markkina. järjestelmällä on hallinnollisia rahanjakojärjes. telmiä paremmat edellytykset hyödyntää re. sursseja tehokkaasti. Mutta se ei tarjoa mitään mahdollisuuksia korostaa humanitaaristen ihanteita, mikä tukisi markkinoilta usein pois. suljettuja vähäosaisia. Siksi on tarpeen muuttaa markkinoiden sosiaalidarwinistista luonnetta auttamalla niitä ihmisiä, jotka eivät muuten kykenisi hyödyntämään välttämättömiä hyödykkeitå tai palveluja.

Markkinat eivät voi heijastaa minkään as teen sosiaalista sitoutumista, elleivät ne ole julkisen vallan jonkinlaisen väliintulon modifioimia (vrt. Wolf, 1988). Julkisen vallan väliintulo on siis edellytyksenä aikuiskasvatuspalvelujen tasaisemmalle tarjonnalle. Laaja ja vankka julkinen sektori ei kuitenkaan takaa sitä, että sosiaalinen sitoutuminen toteutuisi. Tässä asiassa onkin aina kyse siitå, kuinka julkiset resurssit jaetaan ja mikä on muiden kannustimien osuus järjestöjen käyttäytymisessä ja toimintaperiaatteissa.

Norjalaiset pitävät yleensä itsestään selvänä sitä, ettå yhteiskunnallinen tasa-arvottomuus aikuiskasvatuksessa olisi ollut vieläkin suu. rempaa ilman julkisen vallan väliintuloa (vrt. Eide, 1982). Toisaalta ilman julkista aikuiskasvatuspolitiikkaa ja järjestöille kanavoitavia ta. loudellisia kannustimia sosiaalisen sitoutumisen vastuu saattaisi edelleenkin jäädä näiden järjestöjen harteille. Olkoonkin, että vastakkaiset hypoteesit ovat parhaimmillaankin vain oppineiden arvailuja - todennäköisesti oikeita ", on perusteltua esittää provosoiva kysy. mys: olisiko aikuiskasvatuksessa syntynyt enemmän tasa-arvoa ilman toteutettua aikuis. kasvatuspolitiikkaa? Mikäli olettamus, että aikuiskasvatuspolitiikka on vähentänyt järjestö. jen sosiaalista sitoutumista voimakkaasti, pitåä paikkansa, kysymykseen on vastattava myöntåvästi.

\section{Yhteenveto}

Aikuiskasvatuspolitiikan määräämät tukimuodot kohdistuvat aikuiskasvatuspalvelujen tuottajien, pääosin järjestöjen, käyttåytymiseen. Niinpä tavoitteiden onnistuminen riip. puu siitä, miten paljon se todella ohjaa käyttäytymistä haluttuun suuntaan. Näyttåä siltä, että tiettyjen ryhmien tukeminen on tehokkain tapa saavuttaa haluttu lopputulos. Näin voidaan varmistaa, että heikoimmatkin ryhmät saavat asemaansa mahdollisesti kohentavaa aikuiskasvatuksellista tarjontaa. Se, että kysymyksessä on rajattu ihmisjoukko, merkitsee sitä, että yleinen aikuiskasvatuspolitiikka ei vaikuta merkitsevästi vallitsevaan alueelli. seen, sukupuoliseen ja sosio-ekonomiseen eriarvoisuuteen. 
Vapaan sivistystyön järjestöjen työn kannalta edellä olevasta voidaan päätellä, että aikuiskasvatuspolitiikan (mukaanlukien rahallinen tuki) vaikutus on kaksijakoinen. Ensinnäkin se vaikuttaa järjestöjen toimintaan niin, että sosiaalisen sitoutumisen julkituonti nähdään ensisijaisesti viranomaisten tehtävåksi. Tässä yhteydesså tätä voidaan kutsua aikuiskasvatuspolitiikan metavaikutukseksi. Norjassa järjestöjen näkemys omasta roolistaan näyttää ratkaisevasti muuttuneen julkisen rahoituksellisen kannustusjärjestelmän myötä. Alkujaan koulutuksen käynnistäjinä toimineista ja sitä osallistujilta kerätyillä maksuilla ylläpitäneistä järjestöistä on tullut julkisten vallan edustajia, jotka saavat ja jakavat yhteiskunnan varoja. Kun järjestöjä arvostellaan sitoutuneiden aikuiskasvatuskurssien vähentymisestä, ne ovat taipuvaisia vierittämään syyn viranomaisten niskoille: "Emme ole saaneet riittäviä taloudellisia resursseja asian edistämiseksi."

Toisaalta kun ne kerran ovat olemassa, valtionapujärjestelmien laajuus ja rakenne vaikuttavat järjestöjen käyttäytymiseen ja siten välillisesti niiden sosiaaliseen sitoutumiseen. Tätä voidaan kutsua aikuiskasvatuspolitiikan sääteleväksi vaikutukseksi. On selvää, että te. hokkain tapa lähestyä yhdenvertaistamisen tavoitetta on parantaa yhteiskunnan heikompien jäsenien asemaa valikoivien tukimuotojen kautta. Tämä periaate on kuitenkin ristiriidassa laajemman hyvinvointivaltion ihanteen kanssa, sen että hyötyjien määrä on maksimoitavissa per capita -jaon keinoin. Itse asiassa järjestöt tukevat tätä periaatetta hyvin voimakkaasti. Todennäköisin syy kannatukseen on se, että järjestöillä on tapana mitata omaa ja sektorinsa menestystä kurssien ja osallistujien lukumäärällä.

Yhdenvertaistamistavoitteiden taustaa vas: ten nåyttäå siltä, ettå valtionapujärjestelmå ei ole ratkaiseva tekijä aikuiskasvatuksessa, ellei vähävaraisia ryhmiä aseteta etuasemaan. On kuitenkin vaikea kuvitella sellaista politiikkaa, joka tarkoituksellisesti pidättelisi suhteellisesti varakkaampia, jotta muut saisivat heidät kiinni. Ainoa ratkaisu olisi kieltää varakkailta pääsy kursseille. Vaikka tällaista periaatetta sovellettaisiinkin, edellä mainitut paradoksit eivät poistuisi.

Wildavsky'n (1987:287; kts. myös Wolf, 1988:82) epäsuhdan aksiomi (jonka mukaan jokainen toimenpide, jolla pyritään kasvattamaan epäsuhtaa jollakin alueella pakostakin vähentää sitä toisella) näyttää olevan suurin este julkisen, monitavoitteisen, ei-priorisoivan kannustinjärjestelmän toteuttamisen tiellä. Sekä aikuiskasvatuspolitiikan toteuttajat että va. paan sivistystyön järjestöt ovat näin ollen ajau- tuneet umpikujaan, josta ei päästä ennen kuin poliittiset päättäjät asettavat politiikan tavoitteet arvojärjestykseen. Kun tämä on tehty, voidaan niukat resurssit priorisoida tavoitepohjaisesti. Mutta tätä ennen aikuiskasvatusjärjestöiltä ei kannata odottaa mitään merkittävää panosta tasa-arvon lisäämiseksi. Näin ollen, vaikka järjestöjen käyttäytymistä voidaan pitää eräänä vallitsevan eriarvoisuuden välittömänä seurauksena, avain väestöryhmien väliseen yhdenvertaisuuteen on löydettävissä poliittisesta järjestelmästä.

\section{LÄHTEET}

Aamodt, P.O. 1976. Voksenopplring 1969-1974. Oslo: Central Bureau of Statistics.

Bergh, T. 1977. Norsk okonomisk politikk. In T. Bergh and H.O. Pharo (Eds.), Vekst og velstand. (Growth and Prosperity.) Oslo: Norwegian University Press.

Blaug, M. and Mace, J. 1977. Recurrent education: The 'New Jerusalem' ? Higher Education, 6, 277-299.

Brostrom, A. and Ekeroth, G. 1977. Vuxenutbildning och fördelningspoltik. Stockholm: Liber.

Central Bureau of Statistics 1989. Utdanningsstatistikk: Voksenopplring 1987-88. Oslo: Author.

Eide, K. 1982. Utdanning og likhet. Fakkelen, No. 3. Gronlie, T. 1977. Norsk industripolitikk 1945-1965. In T. Bergh and H.O. Pharo (ed.), Vekst og velstand. Oslo: Norwegian University Press.

Hernes, G. 1974. Om ulikhetens reproduksjon. In I forskningens lys. Oslo: Norwegian Council for Research in Social Science and the Humanities.

Hernes, G. 1978. Per capita ideologi og koplingsgevinster. In G. Hernes (ed.) Forhandlingsokonomi og blandingsadministrasjion. Oslo: Norwegian University Press.

Kallerud, B. 1978. Mål for voksenopplring. Trondheim: Norsk voksenpedagogisk institutt.

Knudsen, K. og Ulset, S. 1980. Voksenopplring: organisasjonene og loven. Trondheim: Norsk voksenpedagogisk institutt.

Lov om voksenopplring av 28. mai 1976.

Lovett, T. Adult Education. Community Development and the Working Class. Nottingham: University of Nottingham.

Lund, J. and Nordhaug, O. 1985. Adult education in Norway: Challenges and directions. Paper presented at the Annual Convention of the International League for Social Commitment in Adult Education, Gothenburg/Stockholm, June 1985.

Martinussen, W. 1977. The Distant Democracy. London: Wiley.

Miller, H.L. 1967. Participation of Adult Education: A Force-Field Analysis. Boston: Center for the Study of Liberal Education for Adults. 
Newman, M. 1979. The Poor Cousin: A Study of Adult Education. London: Allen \& Unwin.

Nordhaug. O. 1982. Statens finansiering av voksenopplring: Fordelingspolitiske virkninger. Trondheim: Norsk voksenpedagogisk institutt.

Nordhaug, O. 1983. Distribution of adult education: The Norwegian Case. Adult Education Quarterly, 34, 29-37.

Nordhaug, O. 1984. Voksenopplring og ulikhet. Tidskrift for samfunnsforskning, 25, 187-204.

Nordhaug, O. 1985. Regionale monstre i norsk voksenopplring. Trondheim: Norsk voksenpedagogisk institutt.

Nordhaug, O. 1986. Adult education in the welfare state: Institutionalization of social comitment. International Journal of Lifelong Education, 5, 45-57.

Nordhaug, O. 1991. The Shadow Educational System. Oxford, UK: Oxford University Press (in press). Okun, A. 1975. Equality and Efficiency. The Big Tradeoff. Washington, D.C.: Brookings Institution.

Olsen, J.P. and Saetren, H. 1980. Aksjoner og demokrati. Bergen: Norwegian University Press.

Ot.prp, nro 7 1975. Om lov om voksenopplring. OsIo: Ministry of Education.

Rubenson, K. 1980. Background and theoretical context. In R. Hoeghielm, R. and Rubenson, K. (ed.), Adult education for social change. Research on the Swedish Allocation Policy. Stockholm: liber.

Rubenson, K. 1977. Participation in recurrent education: A research review. Paper presented at meeting for National Delegates on Developments in Recurrent Education, Paris, March 1977.
Setsaas, R. 1985. Voksenopplring i fritida: Deltakelse og rekruttering. Trondheim: Norsk voksenpedagogisk institutt.

Skard, O. 1979. Recent legislation and the Norwegian pattern of adult education. In T. Schuller and J. Megarry (ed.), World Yearbook of Education 1979. Recurrent Education and Lifelong Learning. London/New York: Kogan/Page Nichols.

Soolid, O. 1982. Folkeopplysningsmisjonrene. In S. Bjerkaker and H.M. Wivestad 8ed.), Folkeopplysning i 50 år. Oslo: Samnemnda for studiearbeid/NKS-forlaget.

Stenersen, O. 1977. Ventrekreftene i norsk politikk 1945-1965. In T. Bergh and H.O. Pharo (ed.), Vekst og velstand. Oslo: Universitetsforlaget.

St.meld. $\mathrm{nr}$ 72. 1983. Om lov om voksenopplring. White Paper to the Parliament. Oslo: Ministry of Education and Church.

Van Til. J. 1988. Mapping the Third Sector: Voluntarism in a Changing Social Economy. New York: Foundation Center.

Weisbrod. B. 1988. The Non-Profit Economy. Cambridge, MA: Harvard University Press.

Westwood, S. 1980. Adult education and the sociology of education: An exploration. In J.L. Thompson (ed.), Adult Education for a Change. London: Hutchinson.

Wildavsky, A. 1987. Speaking Truth to Power. New Brunswick, NJ: Transaction Books.

Wolf, C. jr. 1988. Markets and Governments. Cambridge, MA: MIT Press. 


\section{AIKUIISKASVATUS \\ The Finnish Journal of Adult Education \\ Vol. 11, 2/91 \\ ISSN 0358-6197 \\ Summary}

Nordhaug Odd 1991. Aikuiskasvatuspolitiikka ja vapaan sivistystyön järjestöt Norjassa.

- Artikkelissa kåsitellåån vapaan sivistystyön organisaatioiden historrallista sitoutuneisuutta yh. teiskunnalliseen muutokseen, nimenomaan köyhien ja koulutuksellisesti vähäosaisten puo. lesta, sekå tåmån tehtävån syrjäytymistå markkinahakuisen koulutuksen tieltä. Artikkelissa poh. ditaan Norian virallisen aikuiskasvatuspolitiikan tavoitteiden ja taloudellisten tukitoimenpiteiden vaikutusta aikuiskasvatusjärjestojen sosiaaliseen sitoutuneisuuteen. Vaikka valtion ja aikuiskasva. tusorganisaatioiden suhde on monivaikutteinen, ratkaisu eri våestöryhmien vålisen yhdenvertaisuuden saavuttamiseksi on لöydettävissä poliittisesta järjestelmåstä, ei niinkåån aikurskasvatus. järjestöjen toiminnasta.

Aikuiskasvatus 11,2 .
Nordhaug Odd 1991. Public policy and volun. tary organizations in Norway.

- The author deals with the historical com. mitment of voluntary organizations to social changes, especially from the point of view of the poor and educationally underprivileged, and the replacement of this task by market-oriented provision of training. The article also examines the issue of the impact that the goals and financial support of Norway's official adult education policy have on the social commitment of adult edu. cation organizations. Although the relationship between the state and edult education organizations has many facets to it, the solution to achie. ving equality between the various social groups is to be found in the political system and not in what the adult education organizations do. Aikuiskasvatus 11,2. 